\title{
Child with predominant midline stereotypies and infrequent seizures
}

\author{
Bhanudeep Singanamalla, ${ }^{1}$ Priyanka Madaan, ${ }^{1,2}$ Lokesh Saini 이, ${ }^{1}$ Naveen Sankhyan ${ }^{1}$
}

${ }^{1}$ Pediatric Neurology, Post Graduate Institute of Medical Education and Research, Chandigarh, India ${ }^{2}$ Pediatrics, Council of Scientific and Industrial Research, CSIR complex, Library Avenue, Pusa, New Delhi, India

\section{Correspondence to}

Dr Lokesh Saini;

drlokeshsaini@gmail.com

Accepted 30 December 2020

Check for updates

(c) BMJ Publishing Group Limited 2021. No commercial re-use. See rights and permissions. Published by BMJ.

To cite: Singanamalla $B$,

Madaan $\mathrm{P}$, Saini L, et al. BMJ

Case Rep 2021;14:e238764.

doi:10.1136/bcr-2020-

238764

\section{DESCRIPTION}

A 4-year-old boy, sixth born of third-degree consanguineous marriage, presented with a brief unprovoked generalised seizure at 1.5 years of age. Following this, he developed progressive ataxia, vision loss, autistic features with poor eye contact, midline motor stereotypies and cognitive decline. He had unremarkable perinatal and family history. Examination revealed microcephaly, bilateral optic atrophy and ataxia. Electroencephalography (EEG) revealed generalised delta-theta slowing with a paucity of sleep markers (figure 1). Photic stimulation was unremarkable. MRI of the brain revealed diffuse atrophy (cerebellar $>>$ cerebral) (figure 2). A visual evoked potential showed no clear waveforms on either side. Clinical exome sequencing revealed a novel homozygous c.1078C $>$ T (p.Q360*) pathogenic stop gain variant in exon 11 of the MFSD8 gene. This mutation was likely pathogenic and was confirmed by Sanger sequencing. At 6 years of age, the child had no further seizures with midline motor stereotypies, microcephaly, breathing difficulties, insomnia and in a bed-bound state.

The neuronal ceroid lipofuscinosis (NCLs), previously referred to as Batten's disease, is a group of most common autosomal recessive lysosomal storage disorders. They have a common symptom complex of neuroregression, epilepsy and various ophthalmological abnormalities. ${ }^{1}$ MFSD8-related NCL-7 typically begins between 2 and 11 years of age. The initial features usually include infrequent seizures, neuroregression and occasionally stereotypical hand movements. ${ }^{12}$ The characteristic early photosensitivity described for CLN-2 disease may not be often seen. ${ }^{34}$ The other classical EEG findings described in NCL are abundant posterior lead discharges and generalised background slowing. The novel features seen in our case were infrequent seizures, presence of predominant midline stereotypies, lack of abundant posterior discharges and photosensitivity. ${ }^{4}$ Hence, it is important to consider the possibility of NCL in a child with

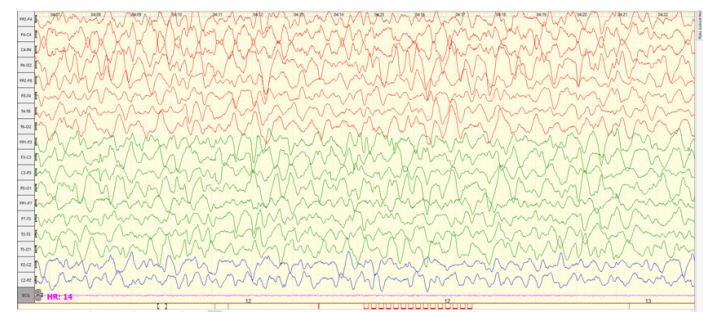

Figure 1 Sleep electroencephalographic 10 s epoch (average montage; sensitivity: $10 \mu \mathrm{V} / \mathrm{mm}$; sweep: $30 \mathrm{~mm} / \mathrm{s}$ ) showing generalised delta-theta slowing along with paucity of sleep markers.

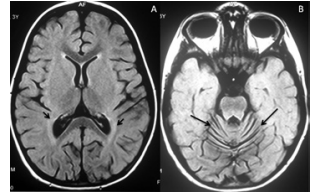

Figure 2 Fluid-attenuated inversion recovery $(A)$ and T1 (B) weighted images of MRI of the brain showing peritrigonal white matter hyperintensities (small arrows) along with diffuse atrophy (cerebellar $>>$ cerebral) (large arrows).

infrequent seizures and midline stereotypies. Genetic diagnosis and counselling play a crucial role in the management of these children.

To conclude, NCL-7 can present with global development delay, midline stereotypies, seizures which are well controlled with anti-seizure drugs with and without autistic features.

\section{Learning points}

- Neuronal ceroid lipofuscinosis (NCL) usually presents with refractory epilepsy, neuroregression and various ophthalmological abnormalities.

- However, NCL-7 can present with infrequent seizures and midline stereotypies.

Contributors BS and PM were involved in patient care, did the literature review and prepared the initial draft of the manuscript. LS and NS were involved in patient care, critically reviewed the manuscript and provided intellectual input

Funding The authors have not declared a specific grant for this research from any funding agency in the public, commercial or not-for-profit sectors.

Competing interests None declared.

Patient consent for publication Parental/guardian consent obtained.

Provenance and peer review Not commissioned; externally peer reviewed.

\section{ORCID iD}

Lokesh Saini http://orcid.org/0000-0003-3153-0736

\section{REFERENCES}

1 Dozières-Puyravel $B$, Nasser $H$, Elmaleh-Bergès $M$, et al. Paediatriconset neuronal ceroid lipofuscinosis: first symptoms and presentation at diagnosis. Dev Med Child Neurol 2020;62:528-30.

2 Kozina AA, Okuneva EG, Baryshnikova NV, et al. A novel MFSD8 mutation in a Russian patient with neuronal ceroid lipofuscinosis type 7: a case report. BMC Med Genet 2018;19:151.

3 Madaan P, Jauhari P, Luhar ZM, et al. Autism, epilepsy, and neuroregression: photosensitivity on electroencephalography solved the riddle. Clin EEG Neurosci 2020;51:399-402.

4 Craiu D, Dragostin O, Dica A, et al. Rett-Like onset in late-infantile neuronal ceroid lipofuscinosis (CLN7) caused by compound heterozygous mutation in the MFSD8 gene and review of the literature data on clinical onset signs. Eur J Paediatr Neurol 2015;19:78-86. 
Copyright 2021 BMJ Publishing Group. All rights reserved. For permission to reuse any of this content visit https://www.bmj.com/company/products-services/rights-and-licensing/permissions/

BMJ Case Report Fellows may re-use this article for personal use and teaching without any further permission.

Become a Fellow of BMJ Case Reports today and you can:

- Submit as many cases as you like

- Enjoy fast sympathetic peer review and rapid publication of accepted articles

Access all the published articles

Re-use any of the published material for personal use and teaching without further permission

Customer Service

If you have any further queries about your subscription, please contact our customer services team on +44 (0) 2071111105 or via email at support@bmj.com.

Visit casereports.bmj.com for more articles like this and to become a Fellow 